\title{
Developing Teaching Materials of Indonesian Food Subtopic Tengger Ethnic Cuisine by Using Online Platform Model as Implementation of Blended Learning and Potential to Support Tourism Promotion of Bromo Tengger Semeru National Park
}

\author{
*Budi Wibowotomo \\ Department of Industrial Technology \\ Universitas Negeri Malang \\ Jalan Semarang 5, Malang 65145, Indonesia \\ *budi.wibowotomo.ft@um.ac.id
}

\author{
Soenar Soekopitojo, Titi Mutiara and Nunung Nurjanah \\ Department of Industrial Technology \\ Universitas Negeri Malang \\ Jalan Semarang 5, Malang 65145, Indonesia \\ mutiaraum@yahoo.co.id.
}

\begin{abstract}
Tengger ethnic cuisine is not yet widely known. To understand the concept of local knowledge and it's related in local food cultures, it needs to be taught formally in school's culinary roles and functions in shaping the culture of ethnic Tengger. It also enables to support ecotourism promotion in the case of ethnic culinary aspects. This paper presents an enrichment of teaching materials in Indonesian Food subtopic Tengger ethnic cuisine based on e-learning platform model. This study intends to identify the culinary competence development as a mediator effective learning Indonesian food through a combination of online learning and face-to-face. The development of teaching materials was formed in two models, which are the structured learning modules and online culinary learning; as implementation of online learning combined / blended learning that can be used in the development of learning tools providing the integration of face-toface direct and indirect. The research method employs the Research and Development model, with approaching technique refers to a modified Borg \& Gall. Instruments of evaluation were adopted from LORI criteria for identifying the combination of online learning content from the subjects of Indonesian food. Research results show it was obtained the learning module that has been verified and meet the basic format containing description, learning materials, summaries, and evaluations. The second model was an online culinary learning platform, divided into Student account and Tutor/Teacher account.
\end{abstract}

Index Terms - e-learning platform model, learning modules, online culinary learning, and Tengger cuisine.

\section{INTRODUCTION}

Indonesian food is one of the subjects of expertise working (MKB) MKB group study areas Catering Program. Study aspects studied are all matters related to food (the staple food, side dishes, and cakes) from various regions in Indonesia. However, certain local culinary ethnic culture in particular has not been evaluated, including Tengger ethnic cuisine. Food as cultural aspects need to be explored further, this time only the tacit knowledge. To understand the concept of local knowledge and relevance in shaping local food cultures Tengger ethnic communities are taught only informally, not taught formally in schools. The role and function of the Tengger ethnic culinary as local wisdom in shaping the culture of the local community is an asset Tengger worldwide in public life both as a daily food or food in traditional ceremonies.

East Java Province has a worldwide tourism asset namely Bromo Tengger Semeru National Park (TNBTS). It became an important asset in addition to its cultural uniqueness in terms of traditional ceremonies Kasodo. At each solemnization always included a variety of specialty foods. In addition to food for the ceremony to-day consumtion Tengger has many distinctive culinary yet widely known. It can be developed to support ecotourism tourism in this case on the ethnic culinary aspects. User behavior and perceptions of protected areas in Indonesia are affected by cognitive interpretation. A study in Bromo Tengger Semeru National Park illustrates that the provision of spare time in protected areas in Southeast Asia require a more powerful contextualization, alternative and better market awareness and conservation if the economic benefits of tourism will be maximized [2],

Research [6] suggests there is a relationship between effective learning, professional competence and achievement of learning for students of Hospitality College. Find a significant correlation between the variables in the culinary professional competence and effective learning. There is a positive correlation between effective learning, professional competence and learning performance, which includes the size of job satisfaction, satisfaction of learning, exercise score and GPA semester. However, there is no correlation between the number of certificates and culinary management skills, culinary professional competence is a mediator for learning and as an effective learning This study intends to identify the culinary competence development as a mediator effective 
learning Indonesian food through a combination of online learning and face-to-face.

Catering program of study related to services that require human resources with adequate vocational skills. Field of expertise catering of tourism especially every time progressed so rapidly with the speed of development and community mobilization. Development of teaching materials culinary enrichment Tengger seen as strategic to be studied by students of Catering. Enrichment of teaching materials developed in the form of modules. [3] Mentions the module is one form of teaching materials that are packed full and systematic, in which includes a set of planned learning experience and is designed to help student's master specific learning objectives. The module contains learning objectives, material or substance of learning and evaluation. The module serves as a learning tool that is self-contained so that students can learn independently according to their own pace. Characteristics of the module according to [9], namely: 1) Self Instructional where students are able to teach yourself with the modules developed; 2) selfcontained where all the learning materials of a competency unit or sub-competencies learned there are in a whole module; 3) stand alone modules developed which do not depend on other teaching materials or should not be used in conjunction with other teaching materials; 4) adaptive where the modules should have a high power adiptif the development of science and technology;

In the information age educational services can reach a wider service without limits, as well as teaching and learning activities can be carried out using the information and communication technology (ICT) increasingly sophisticated. Learning tools can be developed with self-learning models through the available devices using distance learning technology. Implementation of learning is not only restricted to the classroom wall completely done face to face. Daring combinations / blended learning can be used in the development of a combination of face to face learning device directly and indirectly, therefore, demanded the ability of educators to develop learning. On the other hand, students can access learning materials wherever located.

Enrichment development of teaching materials in the course theory and practice is needed to support the implementation of conventional teaching and learning media prepare to create a learning environment that is flexible, easily accessible from anywhere and anytime. System Online combinations (e-learning and face to face) allows students to study the materials independently, and evaluate the learning outcomes. In addition to digital media, materials Tengger ethnic cuisine as e-learning materials can be enhanced by providing guidance text, video and audio, with simulations etc. System online combination learning is an effort to improve the quality of human resources. This system can help create a culture of learning and teaching in accordance with the development of flexible learning demands by the public. This system can also increase competition and HR competencies without having to leave the tasks assigned. It is considered effective in improving vocational skills as an integrated $21 \mathrm{st}$ century skills in the subjects of the study program Indonesian Food Catering.

The teaching materials "Indonesian Food" is one of the subjects that studied in courses catering. Tengger ethnic culinary riches as a field of study which studied need attention and yet never be content and substance of teaching materials used in the curriculum. Each region on the other side can develop your own material appropriate local treasures each with its pros and cons, as local content course material.

Material development "Ethnic Culinary Tengger" in combination online face to face or blended learning is studying development of a limited implementation of blended learning is commonly used in the course of learning Indonesian Food in Catering course be extended indefinitely. Provision of material combinations for online global learning community and share teaching materials available. Furthermore, the researchers can gain insight, develop skills, distributes, and feedback from a broader user with self-learning system. Availability of online material is expected to improve the quality of learning. In addition, the material "Ethnic Culinary Tengger" a very interesting study because the local ethnic cuisine and has implications for the development of tourism in the region of Bromo Tengger Semeru National Park.

Research purposes of the study were as follows:

1) Develop teaching materials as the Tengger ethnic culinary enrichment Indonesia-based food materials online for students Prodi combination Catering State University of Malang

2) Analyze the feasibility of module development of teaching materials as the Tengger ethnic cuisine as Indonesiabased food material enrichment for students online combination Catering department of State University of Malang

3) Analyzing the effectiveness of online learning and face to face with the module development of teaching materials as the Tengger ethnic cuisine as Indonesia-based food material enrichment for students online combination Catering department of State University of Malang

\section{METHOD}

\section{A. Research methods}

The research method development or Research and Development is a research method that is used to produce a product, and the product must go through testing the effectiveness of the product [8]. The research approach or the development of Research and Development refers to a modified Borg \& Gall researchers.

Model development of teaching materials are described as follows. 


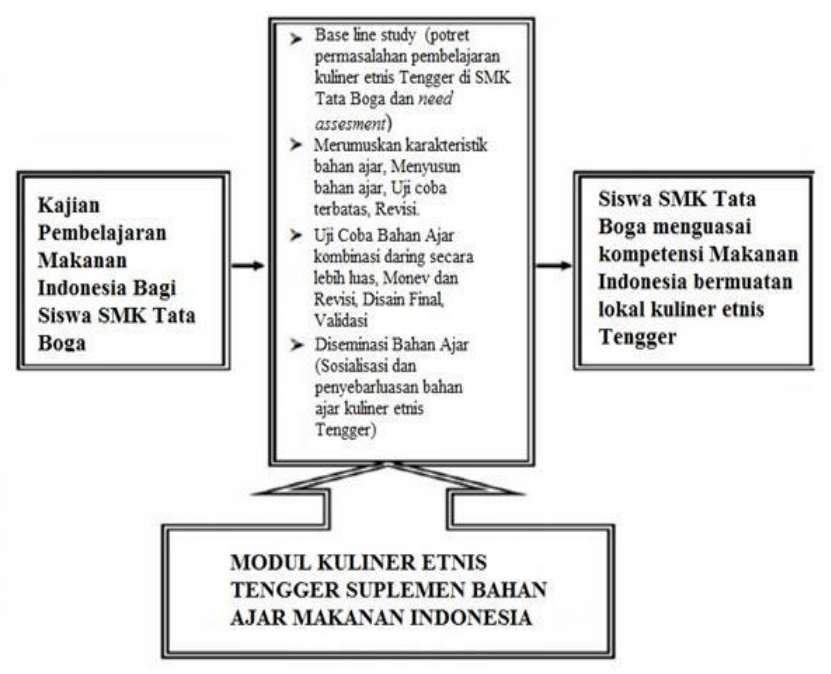

Fig. 1 Teaching Material Development Model

Further research conceptual framework is described as follows.

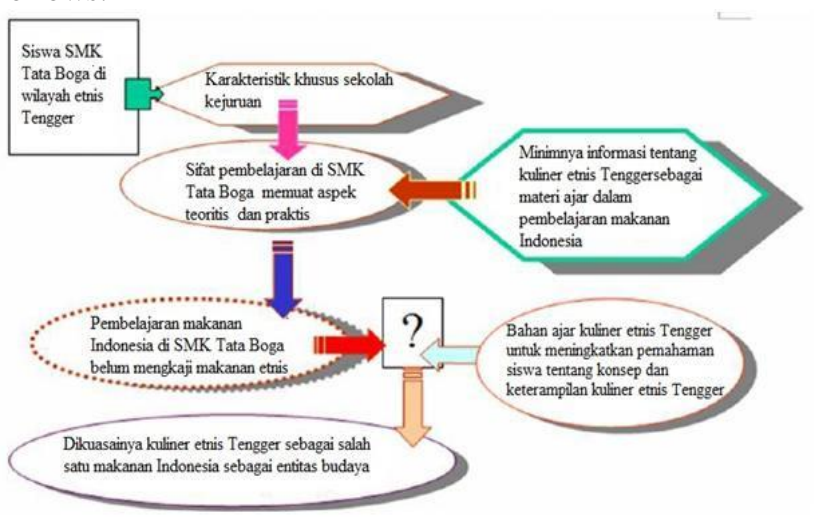

Fig. 2 Conceptual Framework Bahan Ajar Kuliner Ethnic Material Development Tengger

\section{B. Instruments Evaluation of Learning Objects}

Instruments adopted evaluation of criteria for evaluating the content LORI a combination of online learning in the subject of Indonesian food as in the following table.

TABLE 3.1.

INSTRUMENTS EVALUATION OF LEARNING OBJECTS

\begin{tabular}{|c|c|c|c|c|c|}
\hline No. & Signs & 1 & 2 & 3 & 4 \\
\hline \multirow[t]{5}{*}{1} & Quality of content & & & & \\
\hline & Accurate not biased and error-free & & & & \\
\hline & $\begin{array}{l}\text { Clear material structure, subject and sub- } \\
\text { subject language clear, each no } \\
\text { introduction, explanation, and a summary }\end{array}$ & & & & \\
\hline & $\begin{array}{l}\text { Breadth and depth of the material in } \\
\text { accordance with the learning outcomes } \\
\text { and emphasizes the important ideas }\end{array}$ & & & & \\
\hline & $\begin{array}{l}\text { Available trigger or lighters related } \\
\text { discussion topics to bring up the } \\
\text { discussion and / or cultivate new ideas }\end{array}$ & & & & \\
\hline
\end{tabular}

Presentation of content using

communicative language

The substance of learning objects in

accordance with the intended learner characteristics

Variety of learning objects (text, image, audio, video, animations, simulations) are selected appropriate to the needs and character of the learning outcomes

There are examples, example, and exercises with feedback

\begin{tabular}{|c|c|c|c|c|c|}
\hline No. & Signs & 1 & 2 & 3 & 4 \\
\hline & $\begin{array}{l}\text { Listed all references used, specifically for } \\
\text { the online references are provided links to } \\
\text { facilitate learners }\end{array}$ & & & & \\
\hline & $\begin{array}{l}\text { There are terms and their meanings link, } \\
\text { register notation, and the list of symbols, } \\
\text { especially when often referred to in the } \\
\text { text }\end{array}$ & & & & \\
\hline
\end{tabular}
audio, video, animations, simulations) are selected appropriate to the needs and character of the learning outcomes

Providing an example, example, and exercises with feedback

Jot down all the references used, specifically for the online references are provided links to facilitate learners

There are links terms and their meanings,

in the narrative and / or in a glossary

There are a list of notations and symbols especially if often referred to in the narrative

\begin{tabular}{ll}
\hline $\mathbf{2}$ & Feedback and adaptation \\
\cline { 2 - 2 } & $\begin{array}{l}\text { Messages or learning activities geared to } \\
\text { the needs or characteristics of learners }\end{array}$ \\
\cline { 2 - 2 } & $\begin{array}{l}\text { Feedback is comparing the performance of } \\
\text { learners with the criteria established }\end{array}$ \\
\hline 3 & Motivation \\
\cline { 2 - 2 } & $\begin{array}{l}\text { Content relevant to the needs and appeal to } \\
\text { the intended learners }\end{array}$ \\
\cline { 2 - 2 } & $\begin{array}{l}\text { Expectations and success criteria are given } \\
\text { quite realistic }\end{array}$ \\
\hline $\mathbf{4}$ & design presentation \\
& $\begin{array}{l}\text { Visual display clear, readable text, } \\
\text { graphics and charts adequately labelled } \\
\text { and free of visual distractions }\end{array}$ \\
\hline & $\begin{array}{l}\text { Colour, music, and decorative features } \\
\text { esthetical } \\
\text { fun and do not interfere with the learning } \\
\text { outcomes }\end{array}$ \\
\hline $\mathbf{5}$ & reusability interaction \\
\hline $\begin{array}{l}\text { Design interfaces (interfaces) implicitly } \\
\text { inform you how to interact or there are } \\
\text { clear instructions to guide the user }\end{array}$ \\
\hline $\begin{array}{l}\text { Behaviour consistent and predictable } \\
\text { interface }\end{array}$ \\
\hline $\mathbf{6}$ & Accessibility \\
\hline $\begin{array}{l}\text { Can be accessed using the device with } \\
\text { tools and car or portable device }\end{array}$ \\
\hline $\mathbf{7}$ & Reusability \\
\hline $\begin{array}{l}\text { Can be a source of independent learning, } \\
\text { ready to be transferred into the topic and } \\
\text { other learning contexts without much } \\
\text { modification }\end{array}$ \\
\hline
\end{tabular}


III. RESULTS AND DISCUSSION

\section{A. Module}

1) Description

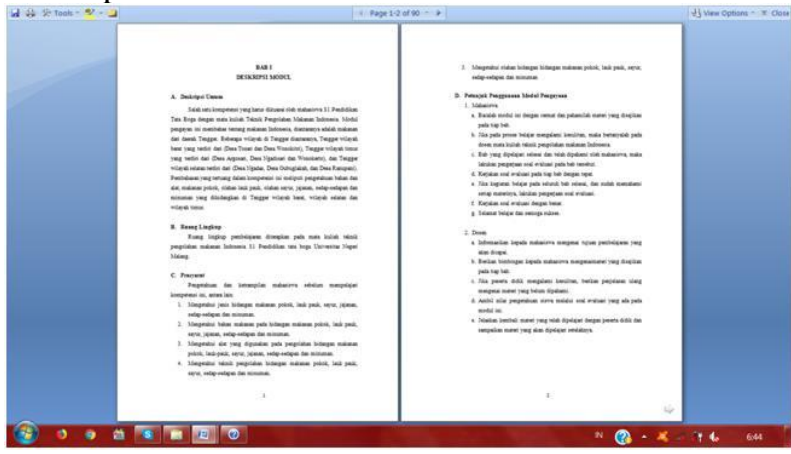

Fig. 3

2) Learning material

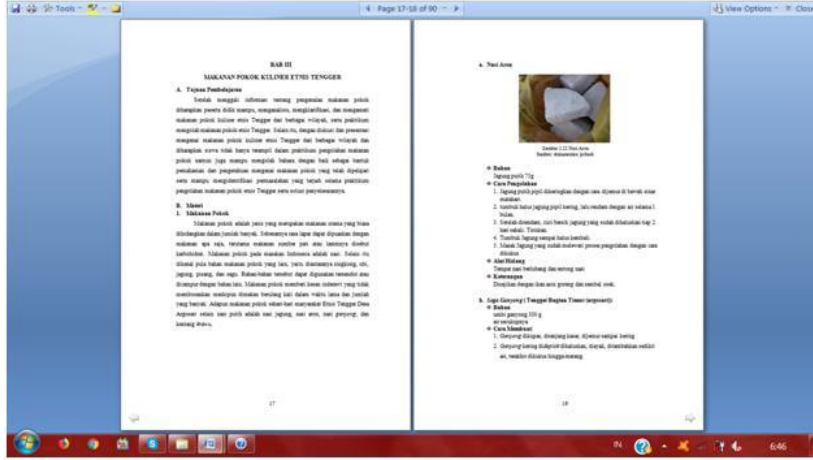

Fig. 3

3) Summary

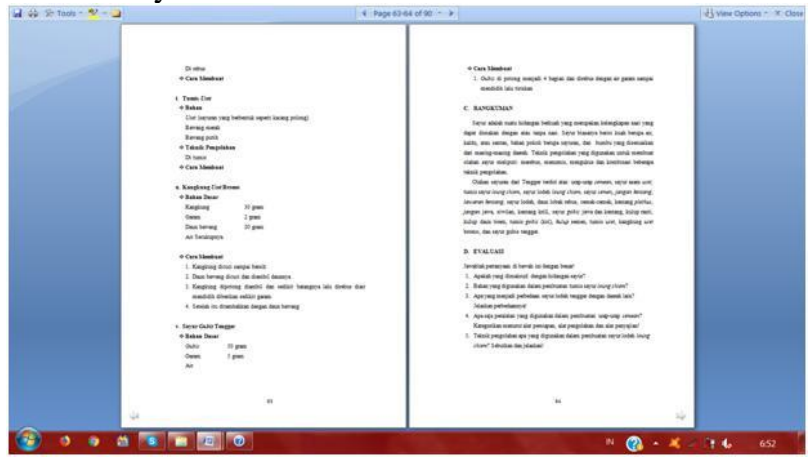

4) Evaluation

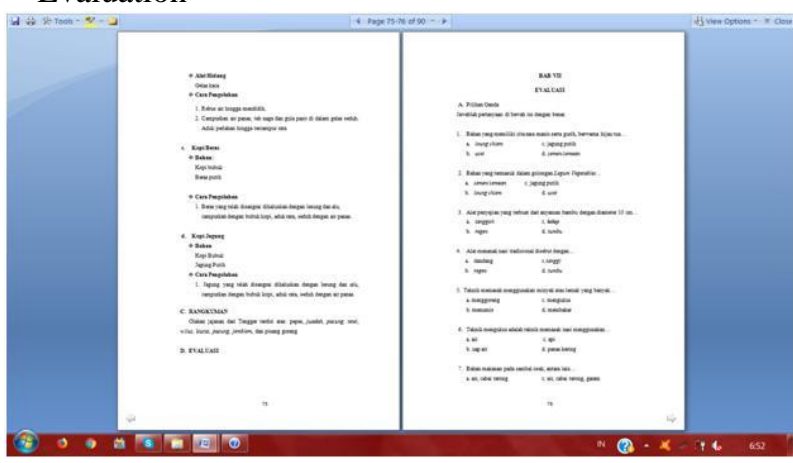

B. Online Culinary Learning Platform

1) Student User
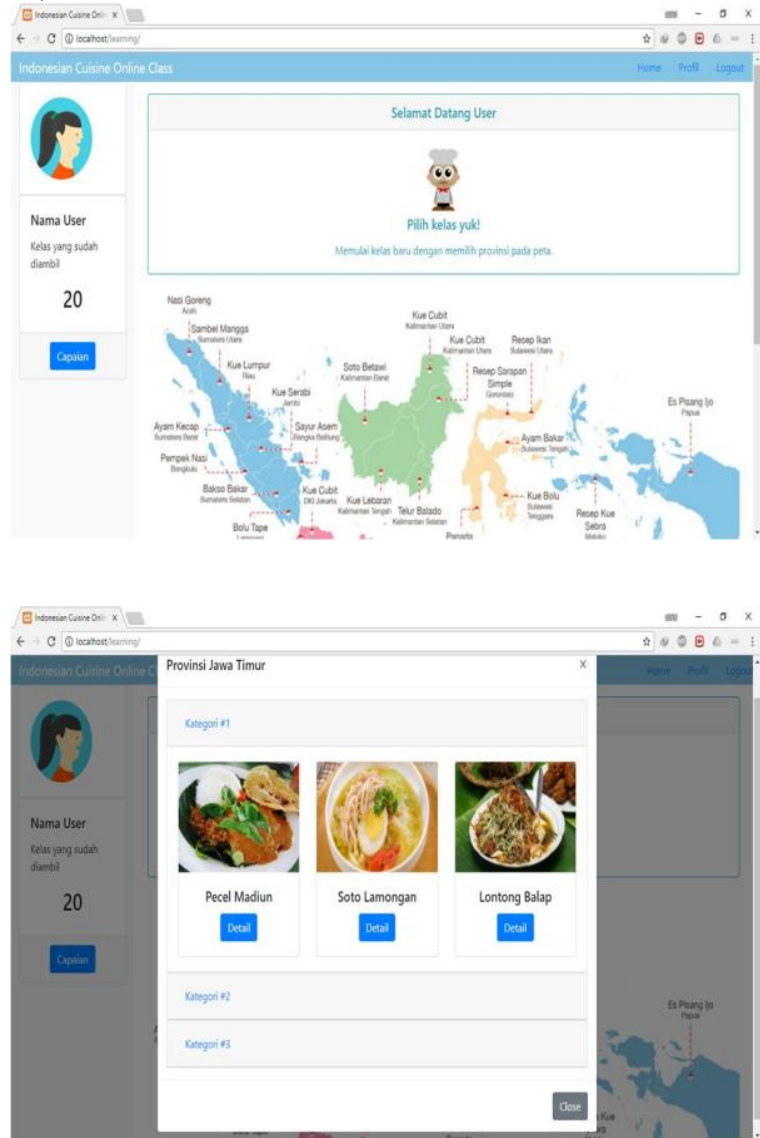

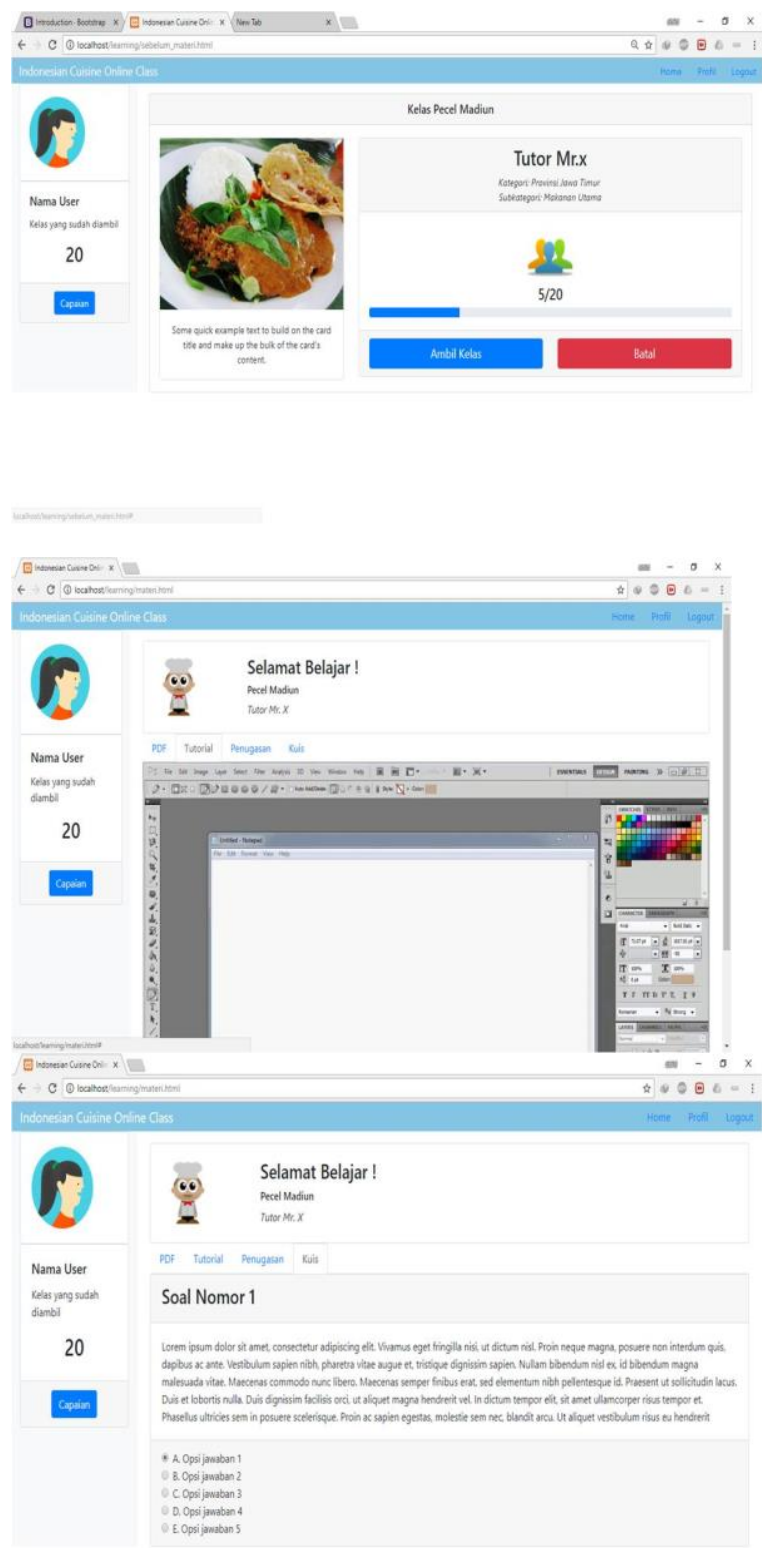

2) Tutor or Teacher User

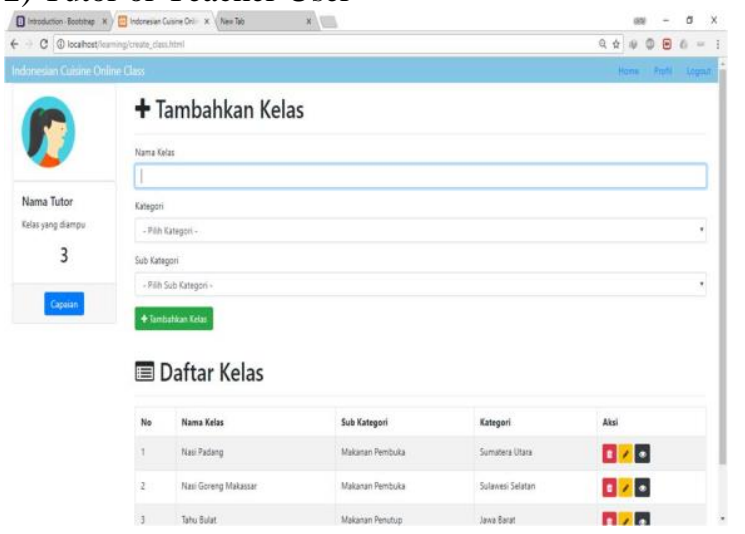

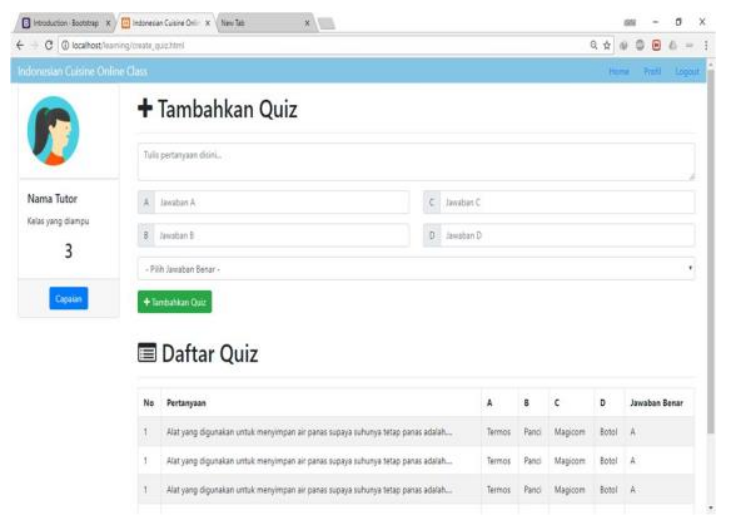

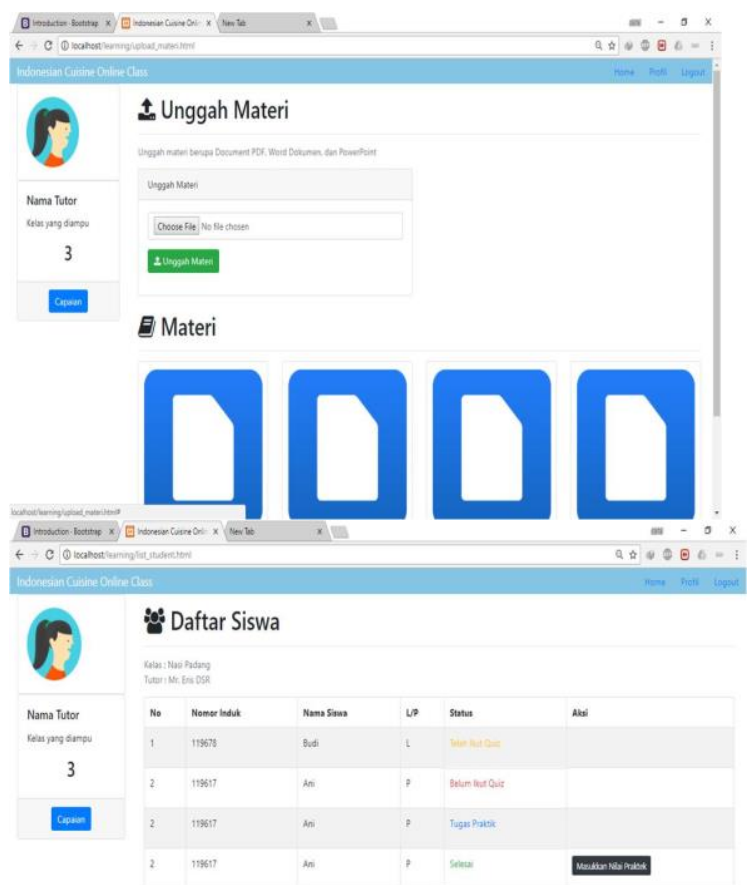

\section{CONCLUSION}

The learning module as Tengger ethnic culinary enrichment Indonesia-based food materials online was obtained. This developing process has been verified and met the basic format containing description, learning materials, summaries, and evaluations. An online culinary course model was developed using online learning platform. This virtual class has two main users which can log in as either Student or Tutor/Teacher. This friendly platform also allows users to customize their accounts freely. 


\section{ACKNOWLEDGMENT}

Authors are thankful to IDB for providing the grant.

\section{REFERENCES}

[1] Barokati, N. and Annas, F. 2013. "Pengembangan pembelajaran berbasis Blended Learning pada matakuliah Pemrograman Komputer (Studi kasus: UNISDA Lamongan)". Jurnal Sistem Informasi (Online), Vol 4 No.5. 2013, (is.its.ac.id/pubs/oajis/index.php/file/download_file/1269, diakses pada 4 Desember 2016).

[2] Cochrane, J. "Indonesian national parks: Understanding Leisure Users". Annals of Tourism Research, 33(4), 979-997. 2006, https://doi.org/10.1016/j.annals.2006.03.018

[3] Daryanto, (2013). Inovasi Pembelajaran Efektif. Bandung: Yrma Widya.

[4] Daggett, W. R. "Preparing students for their Technological Future". Educational Technology, 1-15. 2010, Retrieved from http://www.leadered. com/pdf/Preparing Students for Tech Future white paper.pdf

[5] Hakim, A.B. "Efektifitas penggunaan E-learning Moodle, Google Classroom dan Edmodo". Jurnal STIMIK ESQ (Online), Vol. 2 No.1, 2016. (http://journal.esqbs.ac.id/index.php/I-STATEMENT/article/ download/ 25/27.

[6] Ko, W.-H. "A study of the relationships among effective learning, professional competence, and learning performance in culinary field". Journal of Hospitality, Leisure, Sport \& Tourism Education, 11(1), 1220. 2012, https://doi.org/https://doi.org/10.1016/j.jhlste.2012.02.010

[7] Pawana, G.M, Suharsono, N dan Kirna, I.M. 2014. "Pengembangan multimedia interaktif berbasis proyek dengan model ADDIE pada materi pemrograman web siswa kelas X semester genap di SMK Negeri 3 Singaraja”, 2014. Jurnal Program Pasca Sarjana Universitas Pendidikan Ganesha (Online), Vol 4.

[8] Sugiyono. (2013). Metode Penelitian Kuantitatif, Kualitatif dan R\&D. Bandung: Alfabeta.CV

[9] Widodo, Chomsin S. dan Jasmadi. 2008. Panduan Menyusun Bahan Ajar Berbasis Kompetensi. Jakarta: PT Elex Media Kompetindo. 